\title{
Identifying the relationship between job insecurity and employee performance - An evidence from private colleges in Larkana, Pakistan
}

\author{
Wasim Abbas Awan ${ }^{a l}$ and Abdul Salam ${ }^{b}$ \\ a, Department of Human Resources, SZABIST, Larkana, Pakistan, ${ }^{\mathrm{b}}$ Department of Marketing, SZABIST, Larkana, \\ Pakistan
}

\begin{abstract}
This quantitative study determines the impact of job insecurity on employee job performance. Furthermore, the research includes the detailed study of the factors that impact on job insecurity which make employees insecure and uncertain towards their job particularly in higher secondary education, private colleges in Larkana, Pakistan. Moreover, research was conducted through responses collected by teachers in private colleges of Larkana with the help of close ended questionnaire developed on dichotomous and 5-point Likert scale. Lastly, recommendations were made to increase employee performance for better organizational health.
\end{abstract}

Key words: Job; Job insecurity; performance; private colleges; Larkana

(C) 2014 Beykent University

\footnotetext{
${ }^{1}$ For all correspondence contact to the first author at SZABIST,Larkana ,Pakistan.
} 


\section{Introduction}

Generally, budget cut and reorganizations are considered as result of economic and technological changes. Contemporary, rapid changes in organizations are taking place around the world to cope up with intensified global competition and are becoming the cause of bringing change in nature of work. Thus, the role of employee is getting uncertain (Sverke, et al., 2006). These changes bring imbalance in labor market which becomes the cause of creating variability in retention and employment security. In order to bring reduction in cost and increasing competitiveness most of industrialized countries are found involved in practice of restructuring, layoffs, and right sizing (Cascio, 1998). This adopted practice has obsoleted the idea of long life employment. Today, in most of countries workforce expansion or contraction is in the verge of market conditions. Consequently, these circumstances weaken the employer-employee relationship and suggest an alternative solution to induct contractual and outsourced employees. Furthermore, these alternatives create a sense of insecurity in jobs, create negative set of perception about organizations and decrease the sense of stability cumulating uncertainty in job (Sverke, et al., 2006).

In education sector, particularly higher secondary education in private colleges of Larkana, job insecurity is considered as a tool to bring variability in performance of teachers. Apparently, it is considered that job insecurity accounts for change in performance but it is not fatal that the change will always be positive.

This study will describe the relationship between job insecurity and performance in private colleges providing higher secondary education in Larkana. In this paper, it has been questioned to identify the relationship between job insecurity and performance.

\section{Literature Review}

Job insecurity is a state when employee starts perceiving threaten and powerlessness to perform any thing (Owolabi, 2011). Job insecurity impacts on employee wellbeing, their families and their social life related problems. In 1989 a study was conducted by Quin and Lotempio which showed significant relation between job insecurity and job dissatisfaction (Owolabi, 2011). Most of the studies conducted by different researchers in different span of time i.e. Ferrie, Newman, Shipleya, Marmot \& Stansfeld (2005), Lee, Berkman, Kawachi \& Colditz (2004) have found significant negative relationship between job insecurity and employee wellbeing (Owolabi, 2011).

Working life had been changed drastically over last decades. As a result of these observed changes job insecurity is a new emerging concern in contemporary world which had driven the attention of scholars (Sverke, et al., 2006). The most preferred option to increase profit and reduce cost is to disturb the number of employees by contracts, early departure, layoffs, and outsourcing or in a wide range by adopting mergers, acquisitions and even through privatization (Burke, et al., 2000). Furthermore, another practice which was used in 1980s and 1990s in United States, Europe and Asia is downsizing, literature reveals that more than three million employees doing white collar jobs were eliminated (Rifkin, 1995). Consequently, these activities have increased the concern about job security.

In early 70s job security was termed as motivator but later becomes stressor (Hacman, et al., 1975). In addition, another research was carried out in mid of $80 \mathrm{~s}$ which revealed the shifted construct of job security from motivator to stressor (Greenhalgh, et al., 1984). Literature reveals many definitions of job insecurity characterizing on the basis of employee perception and the understanding of work environment 
employee is working in. Some researchers classify it as contextual result of organization as there is a direct relation between contextual phenomenon of organization and job insecurity and other in contrast explain it as unemployment in society has direct relation with job insecurity (Gallie, et al., 1998).

There are many other definitions of job insecurity in other broader perspectives which are as follows (Mohr, 2000),

\section{Job insecurity by experiencing greater level of insecurity}

Job insecurity by organizational conditions and constraints

Job insecurity by experiencing subjective analysis of employment

Job insecurity by conducting practice of layoffs in corresponding organization

Consequently, these all factors (subjective \& objective) affect performance, satisfaction and commitment to organization. It is discussed in literature that job insecurity is greatly experienced by permanent rather temporary employees. Moreover, permanent employees were found at lower level of performance, satisfaction and commitment (De Witte, et al., 2003).

Alternatively, there are five other phases of job insecurity (Roskies, et al., 1990)

\section{Expectation to be terminated}

\section{Early retirement}

\section{Demotion}

\section{Weakened working conditions}

Apart from mentioned factors, researchers also argued to have a differentiation in qualitative and quantitative aspects of job insecurity. The quantitative aspects is aroused by the conceptualization of global paradigm while quantitative is fear of losing features of job which are important to incumbent (Hellgren, et al., 1999).

Additionally, there are some demographics factors which may impact on job security. Considering different age brackets; people in the age of 40s are considered to raise children hence experience more job insecurity than of those who have no such responsibility. Similarly high job insecurity is experienced by old age employees (De Witte, et al., 2003). Gender may play an important role in creating job insecurity. It is evident from studies that men face more job insecurity than women (Kinnunen, et al., 1999). However, it is also discussed that a woman having responsibility of earning bread may encounter same insecurity as of man (De Witte, 1999). Socioeconomic status has an impact on job security. It is revealed that people having low status are more threatened about loss of job and feel greater insecurity. It is often due to the fact that low status people have low education therefore they try to stick with the present job and fear of unemployment creates high level of insecurity (Sverke, et al., 2006). Employment contracts are also influencing upon job insecurity. Full time employees have comparatively less level of job insecurity them temporary employees (Barling, et al., 1996). On the other hand, job insecurity among part time workers is un-decidable in literature (De Witte, et al., 2003). Furthermore, association with unions, having a union membership is considered as a social support which is inversely related to job insecurity. Unions have strong influence on management having united voice which may affect management in favor of employee. It is also discussed in literature that nonmembers have greater level of job insecurity than members (Sverke, et al., 2006). 
Job insecurity leads to uncertainty and unpredictability about employment. This uncertainty creates stress; similarly, it impacts on health, attitude and behavior (Sverke, et al., 2003). It is discussed that job security has an indirect relationship with health. Moreover it is also discussed that subjective job insecurity has greater impact on health (Mohr, 2000). Nevertheless, in organizational context employees react to job insecurity which impacts on organizational effectiveness (Greenhalgh, et al., 1984). There are many attitudes attached to job insecurity, the most common is job satisfaction. Similarly, there is a negative relationship exists between job insecurity and job satisfaction (Sverke, et al., 2006). There is another discussion available in literature as employees will be less devoted to organization if they have perceived the job insecurity. This will lead to higher turnover and employees will be more in to quitting from the current job (Burke, et al.).

The performance of employee will also get affected to the extent of feeling job insecurity. Literature shows that there is an association between job insecurity and self-related performance (Rosenblatt, et al., 1999). Moreover, studies also reveals that employees having fear of job insecurity perform more to become valuable in order to confirm their stay with organization (Sverke, et al., 2001). Other studies shows negative relation of job insecurity with well-being of employees, their attitudes, job involvement and trust over management (Sverke, et al., 2002).

\section{Research and Methodology}

\subsection{Research Data and Description}

This research is descriptive in nature, the type of investigation was causal and researcher interference was moderate. It was a non-contrived study and field experiment is used for this research. The unit of analysis was individual and the time horizon was cross sectional.

The respondents of the study are permanent (full- time) teachers of private colleges in Larkana.

The target population for this study comprises fifty five permanent teachers teaching in three private colleges in Larkana.

Convenience sampling is used by researcher and the data was collected through primary source (questionnaire). A close ended questionnaire was used containing dichotomous and Likert scaling. It was distributed among employees of private colleges in Larkana and sample of 50 respondents were collected.

We have taken sample of fifty respondents from three private colleges in Larkana. The sample was determined on the basis of study conducted by Krejcie \& Morgan (1970).

$$
\mathrm{s}=\mathrm{X}^{2} \mathrm{NP}(1-\mathrm{P}) \div\left[\mathrm{d}^{2}(\mathrm{~N}-1)+\mathrm{X}^{2} \mathrm{P}(1-\mathrm{P})\right]
$$

$\mathbf{s}=$ required sample size

$\mathbf{X}^{2}=$ the table value of chi-square for 1 degree of freedom at the desired confidence level (3.841).

$\mathbf{N}=$ the population size

$\mathbf{P}=$ the population proportion (assumed to be .50 since this would provide the maximum sample size).

$\mathbf{d}=$ the degree of accuracy expressed as a proportion $(.05)$. 


\subsection{Research Hypotheses}

$\mathbf{H}_{\mathbf{0 1}}=$ There is no association between job insecurity and performance.

$\mathbf{H}_{02}=$ There is no association between job insecurity and age.

$\mathbf{H}_{\mathbf{0}}=$ There is no association between performance and age.

$\mathbf{H}_{04}=$ There are no significant differences between the impact of the age on performance.

$\mathbf{H}_{05}=$ There are no significant differences between the impact of the gender on performance.

$\mathbf{H}_{\mathbf{0 6}}=$ There are no significant differences between the impact of the gender on job insecurity.

\subsection{ResearchModel}

This research is descriptive in nature. The type of investigation is causal and researcher interference is moderate. It is a non-contrived study and field experiment is used for this research. The unit of analysis is individual and the time horizon is cross sectional. Convenience sampling is used and the data is collected through primary source (questionnaire). A close ended questionnaire is used containing dichotomous and 5 point Likert scaling. It was distributed among teachers of private colleges in Larkana and sample of 50 respondents were collected.

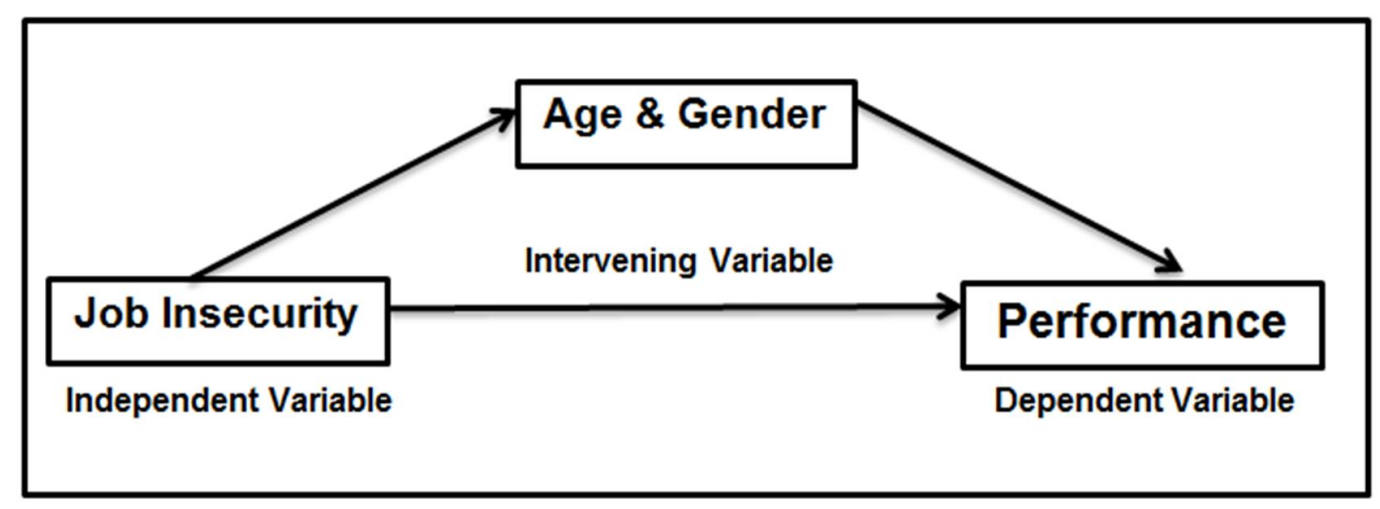

\section{Findings}

\subsection{Reliability Statistics}

The reliability statistics of the questionnaire is measured by Cronbach's alpha test. In order to measure the internal consistency of the questionnaire on same construct the recommended tool is Cronbach's alpha (Cronbach , 1951). The test statistics are as follow:

Table 1: Reliability Statistics

\begin{tabular}{|r|r|}
\hline Cronbach's Alpha & N of Items \\
\hline & .678 \\
\hline
\end{tabular}

Source: This research

The reliability statistics is $\mathbf{0 . 6 7 8}$ which is significantly accepted for the further analysis (George \& Mallery, 2003). 


\subsection{Descriptive analysis of demographics}

The sample was divided among four demographic constructs; gender, designation, age and experience. Among these our sample comprised on seventy percent male, fifty six percent were lecturers, sixty eight percent were in age bracket of 20 to 30 and sixty four percent of the respondents were having experience of at most four years respectively.

Table 2: Descriptive analysis of demographics

\begin{tabular}{|l|l|}
\hline a. Gender \\
\hline 1. Males & $70 \%$ \\
\hline 2. Females & $30 \%$ \\
\hline b. Designation & \\
\hline 1. Teaching Assistant & $26 \%$ \\
\hline 2. Lecturers & $56 \%$ \\
\hline 3. Assistant Professors & $16 \%$ \\
\hline 4. Professors & $2 \%$ \\
\hline
\end{tabular}

\begin{tabular}{|l|l|}
\hline c. Age & $24 \%$ \\
\hline 1. Less than 20 & $68 \%$ \\
\hline 2. 20- 30 & $8 \%$ \\
\hline 3. $30-40$ & $0 \%$ \\
\hline 4. 40 and above & \\
\hline d. Experience & $26 \%$ \\
\hline 1. Less than 1 year & $64 \%$ \\
\hline 2. 1- 4 Years & $0 \%$ \\
\hline 3. 4- 7 years & $6 \%$ \\
\hline 4. 7- 10 years & $4 \%$ \\
\hline 5. 10 and above & \\
\hline
\end{tabular}

\subsection{Data analysis}

In collected sample majority (seventy percent) of the respondents were permanently employed. Moreover, forty percent of the total respondents were expecting to be with new employer in next twelve month. This opinion is backed by an expected bankruptcy and later anticipating getting merger with another organization in next twelve months.

\subsubsection{Descriptive statistics}

i.Relationship between Age, Performance and Job insecurity

Table 3: Spearman's rho correlation

\begin{tabular}{|c|c|c|c|c|}
\hline \multicolumn{2}{|c|}{ Spearman's rho } & Age & Performance & JiS \\
\hline \multirow[t]{2}{*}{ Age } & Correlation Coefficient & & $.408^{* * *}$ & $-.286^{*}$ \\
\hline & Sig. (2-tailed) & & .003 & .044 \\
\hline \multirow[t]{2}{*}{ Performance } & Correlation Coefficient & $.408^{* *}$ & & $-.595^{* *}$ \\
\hline & Sig. (2-tailed) & .003 & & .000 \\
\hline \multirow[t]{2}{*}{$\mathbf{J i S}$} & Correlation Coefficient & -.286 & $-.595^{* *}$ & \\
\hline & Sig. (2-tailed) & .044 & .000 & \\
\hline
\end{tabular}

**. Correlation is significant at the 0.01 level (2-tailed).

*. Correlation is significant at the 0.05 level (2-tailed).

From the above Table 3, there is a low positive correlation exist between age and performance $(n=50, .408, p<0.05)$ therefore we reject the null hypothesis $\left(\mathbf{H}_{\mathbf{0 3}}\right)$ and state that there is an association between age and performance which is statistically significant. Furthermore, there is week negative correlation exist between age and job insecurity $(n=50,-.286, p<0.05)$ which is not negligible, therefore 
we reject the null hypothesis $\left(\mathbf{H}_{\mathbf{0 2}}\right)$ and state that there is an association between age and job insecurity which is statistically significant. Moreover, there is moderate negative correlation exist between performance and job insecurity $(n=50,-.595, p<0.05)$ therefore we reject the null hypothesis $\left(\mathbf{H}_{01}\right)$ and state that there is an association between performance and job insecurity which is statistically significant.

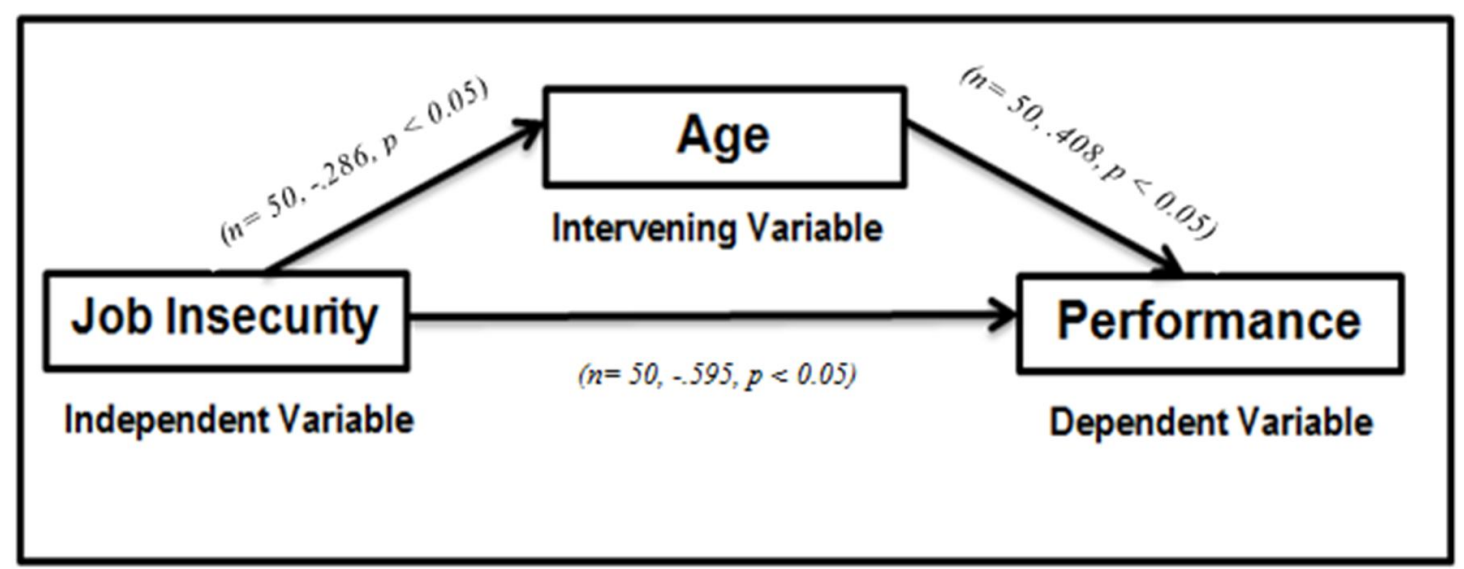

Figure 1: Graphical representation of correlation

i. Measuring significance of Age and Gender with Performance and Job insecurity

Table 4a: Kruskal- Wallis test statistics

\begin{tabular}{|l|c|c|c|c|c|c|}
\hline \multirow{2}{*}{ Kruskal- Wallis } & \multicolumn{3}{|c|}{ Performance } & \multicolumn{3}{c|}{ Job insecurity } \\
\cline { 2 - 7 } & $\boldsymbol{d} \boldsymbol{f}$ & Chi- square & Sig. & $\boldsymbol{d f}$ & Chi- square & Sig. \\
\hline Gender & 1 & 5.365 & 0.021 & 1 & 4.085 & 0.043 \\
\hline
\end{tabular}

Table 5b: Kruskal- Wallis test statistics

\begin{tabular}{|l|c|c|c|}
\hline \multirow{2}{*}{ Kruskal- Wallis } & \multicolumn{3}{|c|}{ Performance } \\
\cline { 2 - 4 } & $\boldsymbol{d f}$ & Chi- square & Sig. \\
\hline Age & 2 & 8.208 & 0.017 \\
\hline
\end{tabular}

To identify the significance difference between age, gender, performance and job insecurity KruskalWallis test is used. There was a significance difference between the impact of age on performance $(p=.017<0.05)$, gender on performance $(p=.021<0.05)$, gender on job insecurity $(p=.043<0.05)$ therefore we reject the null hypothesis $\left(\mathbf{H}_{04}\right),\left(\mathbf{H}_{05}\right)$ and $\left(\mathbf{H}_{06}\right)$ respectively.

\section{Conclusions}

The quantitative research has shown that there is a negative relationship exists among age, performance and job insecurity. It is found that people having an age between 20- 30 years have greater concerned for job insecurity. Similarly, an individual when reach to 40 s do not worry about insecurity of the job. In our case it contradicts with researches conducted determining relationship between age and job insecurity (i.e. De Witte, et al., 2003). Moreover, there is found a significance difference in performance of different age groups (i.e. De Witte, et al., 2003). However, it is also evident from study that age and performance is positively associated which is indeed one of the main causes of creating less job insecurity in age of 40s. 
Besides, gender also plays an important role in specifying job insecurity and performance. There is a significance difference found in the level of performance and extent of job insecurity with gender. Our analysis has depicted more apprehension of job insecurity in men which is evident in early researches (i.e. Kinnunen, et al., 1999).

In literature, there is a negative correlation exists between performance and absenteeism (Sverke, et al., 2006), when performance decreases absenteeism increases, in our case decrease in performance may lead to decrease in absenteeism in private colleges at Larkana. Furthermore, decrease in performance will also impact on their social contacts, income and personal development (De Witte, 1999). As job security increase the frustration towards work will also increase which will impact on performance inversely (Lazarus, et al., 1984).

Additionally, greater insecurity in job decreases the psychological health (Sverke, et al., 2006) which will impact on behavior and attitudes of the people between age of 20-30, this may impact on their productivity in long run. People in age bracket of 20- 30 then switch their jobs rapidly which increases the turnover (Burke, et al.) in private colleges at Larkana.

It is recommended to introduce counseling, mentoring and coaching sessions, sharing of expectations from management to individuals and explaining policies to minimize the deviations. This will surely lead to eustress and energies will be invested in proper directions rather thinking job security.

In further researches different demographics can be included (i.e. marital status, education, salary etc.) to understand better the relationship of insecurity and performance.

\section{References}

Barling J. and Kelloway K. E. Job insecurity and health: The moderating role of workplace control [Journal]. - 1996.

Burke R J and Cooper C L The organization in crisis: Downsizing,restructuring, and privatization [Report]. - [s.1.] : Oxford, 2000.

Burke R. J. and Nelson D. Mergers and acquisitions, downsizing, and privatization : A North American perspective [Journal]. - [s.l.] : Washington, DC. American Psychological Association.

Cascio W. F. The new organizational reality: Downsizing, restructuring, and revitalization [Report]. Washinston DC : American Psychological Association, 1998.

Cronbach L.J. Coefficient alpha and the internal structure of tests [Journal]. - [s.1.] : Psychometrika, 1951. - 3 (297-334) : Vol. 16.

De Witte H. and Näswall K. "Objective" vs. "Subjective" job insecurity: Consequences of temporary work for job satisfaction and organizational commitment in four European countries [Report]. - [s.1.] : Economic and Industrial Democracy, 2003. - pp. 209-312.

De Witte H. Job insecurity and psychological well-being: Review of the literature and exploration of some unresolved issues [Journal]. - [s.1.] : European Journal of Work and Organizational Psychology, 1999.

Gallie D [et al.] Restructuring th employment relationship [Report]. - [s.1.] : Oxford Clarendon Press, 1998.

George D. and Mallery P. SPSS for Windows step by step: A simple guide and reference. [Journal]. [s.1.] : Boston: Allyn and Bacon, 2003. 
Greenhalgh L and Rosenblatt Z Job insecurity: Toward conceptual clarity [Article] // Academy of Management Review. - 1984. - pp. 438-448.

Hacman J R and Oldham G R Development of the Job Diagnostic Survey [Journal] // Journal of Applied Psychology. - 1975. - pp. 159-170.

Hellgren J., Sverke M. and Isaksson K A two-dimensional approach to job insecurity: Consequences for employee attitudes and well-being [Journal] // European Journal of Work and Organization Psychology. 1999. - pp. 179-195.

Kinnunen U. [et al.] Perceived job insecurity: A longitudinal study among Finish employees [Article]. [s.1.] : European Journal of Work and Organizational, 1999. - pp. 243-260.

Krejcie, R. V. and Morgan, D. W. Determining Sample Size For Research [Journal]. - [s.l.] : Education and Psychological measurement, (1970).

Lazarus R. S and Folkman Stress appraisal and coping [Report]. - New York : Springer, 1984.

Mohr G. B. The changing significance of different stressors after the announcement of bankruptcy: A longitudinal investigation with special emphasis on job insecurity [Journal] // Journal of Organizational Behavior. - 2000. - pp. 337-359.

Owolabi Ademola B Effects of Reengineering in Banks on Employees Perception of Job Security [Report]. - [s.1.] : Journal of Management and Strategy, 2011.

Rifkin J The end of work: The decline of the global labor force and the dawn of the post-market era [Report]. - New York : [s.n.], 1995.

Rosenblatt Z., Talmud I. and Ruvio A. A gender-based framework of the experience of job insecurity and its effects on work attitudes [Journal]. - [s.l.] : European Journal of Work and Organizational Psychology, 1999.

Roskies E. and Louis-Guerin C. Job insecurity in managers: Antecedents and consequences [Journal] // Journal of Organizational Behavior. - 1990. - pp. 345-359.

Sverke M [et al.] Job insecurity and union membership: European union in the wake of flexible production [Report]. - Brussels : P.I.E- Peter Lang, 2006.

Sverke M. and Goslinga S. The consequences of job insecurity for employers and unions: Exit, voice, and loyalty [Journal]. - [s.1.] : Economic and Industrial Democracy, 2003.

Sverke M. and Hellgren J. Exit, voice, and loyalty reactions to job insecurity: Do unionized and nonunionized employees differ? [Journal]. - [s.1.] : British Journal of Industrial Relations, 2001.

Sverke M., Hellgren J. and Näswall K. No security: A meta-analysis and review of job insecurity and its consequences. [Journal]. - [s.1.] : Journal of Occupational Health Psychology, 2002.

Sverke Magnus , Hellgren Johnny and Näswall Katharina Job insecurity: a literature review [Journal]. 2006. 